\title{
Death by Mangle: \\ Domestic Technology and Eugenics in Samuel Butler's \\ Erewhon
}

David Gillott

IN THE 'BOOK OF THE MACHINES' chapters of Samuel Butler's novel Erewhon (1872), there is a curious detail that repays some consideration. The episode purports to be a translation from the Erewhonian of an anti-machine tract which sparked the civil war between technophiles and technophobes some five hundred years earlier. The technophobe who wrote the work is concerned that machines will evolve to such an extent that mankind will become extinct, and initially proposes, therefore, that all machines should be destroyed. However, he later concedes that, such is man's dependence on them, the complete destruction of all machines would itself lead to the extinction of mankind in six weeks. Thus, he comes to a compromise with his technophile opponents, and decides that only the most highly-developed machines, those invented in the last 271 years, should be destroyed, leaving only the more primitive machines in the service of man. The specificity of the period is noteworthy in itself, but this short paper will examine the significance of another detail of this anti-machine tract. The period chosen 
was agreed upon by all parties after several years of wrangling as to whether a certain kind of mangle which was much in use among washerwomen should be saved or no. It was at last ruled to be dangerous, and was just excluded by the limit of 27I years.

This mangle, then, was the oldest machine to be destroyed, and was destroyed because it posed a future threat to humanity.

Surprisingly, none of the major critical editions of the text deem this detail worth mentioning. Why did Butler choose the mangle as the oldest machine to be excluded from Erewhon? And what conclusions can we draw from this choice about Butler's nascent evolutionary theories? Some clues can be found in periodicals and novels of the time, in which there are several references to mangles as domestic machines by which the poor could earn a living by taking in laundry, thus avoiding the humiliation of the workhouse. In 'Janet's Repentance', one of George Eliot's Scenes of Clerical Life (1858), Mr Jerome, retired corn-factor and one of the richest men in the parish, has many charities, but his one great object is to

keep industrious men an' women off the parish. l'd rether give ten shillin' an' help a man to stan' on his own legs, nor pay half-a-crown to buy him a parish crutch; it's the ruination on him if he once goes to the parish.

He cites the example of Sally Butts, who, for lack of charity, had to sell her mangle to raise money, in the process losing the means of self-help, with the implication that she became dependent on the parish workhouse.

However, although it provides the means of self-help, the ownership of a mangle is nevertheless often represented as a badge of shame, compared with, for example, the relative gentility associated with the ownership of the more modern domestic sewing-machine. An 1864 article in the periodical Once a Week notes that

Of old, the mangle was an ignoble instrument to which many persons of refinement, who had been reduced in life, were forced to submit; but the sewing-machine, whilst it would entail no such sense of degradation, would prove a little fortune to many a poor woman.

Of course, the mangle as a mark of humiliation is most memorably represented in Nicholas Nickleby (1838-39), when we learn of the vertiginous fall from grace, if 'grace' is the right word, of Mantalini. In the penultimate chapter of the novel, we see this foul-mouthed erstwhile milliner in the cellar of a laundress, 'grinding $[\ldots]$ as if for very life at the mangle, whose creaking noise, mingled with [the laundress's] shrill tones, appeared almost to deafen him'.

In these examples, therefore, the ownership or operation of a mangle is represented in negative terms, a humiliating alternative to a life in the workhouse. There is to be found, however, a far more ambiguous portrayal of mangle ownership. In Our Mutual Friend (1864-65), the reader is presented with a description of the inside of Betty Higden's cottage when the Boffins visit her in search of an orphan to adopt: 
It was [...] perceived to be a small home with a large mangle in it, at the handle of which machine stood a very long boy, with a very little head, and an open mouth of disproportionate capacity that seemed to assist his eyes at staring at the visitors. In a corner below the mangle, on a couple of stools, sat two very little children: a boy and a girl; and when the very long boy, in an interval of staring, took a turn at the mangle, it was alarming to see how it lunged at those two innocents, like a catapult designed for their destruction, harmlessly retiring when within an inch of their heads.

The use of the word 'designed' is interesting here. As critics have pointed out, the word is often used in Our Mutual Friend to signify the teleology of William Paley's natural theology, as opposed to the lack of design in Darwin's evolutionary theory, or to put it into terms Butler used, cunning rather than luck. However, the word is used here in connection with destruction rather than creation, and thus suggests, consonant with the fears of Butler's technophobe in Erewhon seven years later, the danger machines posed to mankind. The threat of death-by-mangle in Our Mutual Friend isn't as farfetched as it appears, and indeed a factory inspection report of 1866 notes how one worker 'who was cleaning a mangle in a bleachworks had one of his arms caught in a pair of cog wheels, and it was so completely destroyed that he died in eight hours afterwards'.

In his 1863 article 'Darwin Among the Machines', Butler observes that machines become smaller and more complex as they evolve and speculates that it would not be too long before the clock became extinct, to be replaced by the watch. Certainly, by the time of the Great Exhibition of 1851, as the illustrations in the catalogue show, mangles had evolved to such an extent that they had shrunk from the huge box-mangle used in industrial laundries or large houses to a size such as could fit in Betty's cramped cottage. In Butler's novel, we learn that it is a crime to be poor in Erewhon. If, therefore, in Erewhon, all mangles have been destroyed, or at least the most highly-evolved smaller mangles, then the poor would be deprived of a means of self-help, and so would be forced out of society and into Erewhon's equivalent of the workhouse, the hospital. In the topsy-turvy world of Erewhon, the hospital, rather than the prison, is the place of punishment. Thus, the exclusion of all mangles in Erewhon suggests that this detail is a comment on the New Poor Law of 1834, which forced the poor into the parish workhouse.

However, in addition to this, it is my contention that the exclusion has more sinister implications. In a chapter on the Poor Laws in Social Statics (1851), Herbert Spencer writes that

\begin{abstract}
it seems hard that widows and orphans should be left to struggle for life or death. Nevertheless, when regarded not separately, but in connection with the interests of universal humanity, these harsh fatalities are seen to be full of the highest beneficence - the same beneficence which brings to early graves the children of diseased parents, and singles out the lowspirited, the intemperate, and the debilitated as the victims of an epidemic.
\end{abstract}

In Butler's novel, the Erewhonians are strikingly beautiful, and the narrator learns that centuries earlier, ugly Erewhonians had been sacrificed. In the 
dispute between the technophobes and the technophiles, even the latter feared that by allowing machines to evolve, this would

\begin{abstract}
so equalise men's powers, and so lessen the severity of competition, that many persons of inferior physique would escape detection and transmit their inferiority to their descendants. [The technophiles] feared that the removal of the present pressure might cause a degeneracy of the human body, and indeed that the whole body might become purely rudimentary, the man himself being nothing but soul and mechanism.
\end{abstract}

Butler here appears to be voicing, in post-Darwinian terms, some of Spencer's pre-Darwinian concerns, and at the same time anticipating later nineteenthcentury debates over degeneration and eugenics. Such a reading is even more evident in the second edition (1872) in which 'degeneracy of the human body' becomes 'degeneracy of the human race'.

These concerns are borne out by the fact that the mangle allowed 'persons of inferior physique' and intelligence to earn a living, such as Sloppy in Our Mutual Friend. Sloppy is described by Betty as a 'Natural', which the OED defines as 'a person born with impaired intelligence'. An 1866 article in the periodical Golden Hours gives an account of a visit to Earlswood, an institution for 'idiots' in which the inmates are described turning the mangle in the laundry. The unskilled and mechanical nature of the turning of the mangle is recognised even by Sloppy himself, when he boasts that he is able to operate it even whilst sleeping. However, despite this monotony, for Sloppy, happily, the turning of the mangle is not the pinnacle of his achievements. Betty observes that 'she had seen him handle tools [...] in a surprising manner'. He is also figured as an ex nihilo Creator, being able to construct toys 'out of nothing'. This mechanical ability sees him elevated from lowly and unskilled mangle-turner to be set up by the end of the novel as a skilled cabinet-maker, while Betty, too, moves on from mangling to end her days travelling between Thames-side towns peddling items that she has made herself from her basket, and achieves her wish of dying outside the clutches of the workhouse.

That Sloppy is able to evolve from mangle-turning highlights the eugenic implications of the exclusion of the mangle in Erewhon, an exclusion which would ensure that the Erewhonian race retained its purity. The plausibility of such a conclusion is enhanced by other works. Several critics have noted Butler's idealisation of the 'swell' in his note-books: 'The good swell is the creature towards which all nature has been groaning and travailing together until now. He is an ideal. He shows what may be done in the way of good breeding, health, looks, temper, and fortune'. For Francis Galton, it was precisely this concept of 'good breeding' which he sought to convey by the Greek-derived neologism, eugenics. Furthermore, George Bernard Shaw, a prominent eugenicist, used the term in his novel Cashel Byron's Profession, written in 1883, and serialised in 1885-86, and would later acknowledge his debt to Butler's evolutionary theories in the Preface to Back to Methuselah (1920), and incorporate them into the eugenicist ideas explored in his works. In the disorientation induced by Butler's many inversions of social norms in Erewhon, one can be hard-pressed to pin down the targets of his satire. However, I would suggest that the curious absence of the mangle from 
Erewhon is a serious comment on the Poor Law, and encodes a eugenic vision shared by its author.

Birkbeck College, University of London 